\title{
The Diversity of Rattan Types at Various Height of Growing Areas in Rompo Village Lore Lindu National Park Area, Central Sulawesi Province, Indonesia
}

\author{
Imran Rachman*, Adam Malik, Naharuddin Naharuddin, Andi Sahri Alam \\ Faculty of Forestry, Universitas Tadulako, City of Palu 94118, Indonesia
}

Corresponding Author Email: imranrachman@untad.ac.id

https://doi.org/10.18280/ijdne.160215

Received: 21 January 2021

Accepted: 5 April 2021

\section{Keywords:}

rattan species, diversity, Lore Lindu National Park

\begin{abstract}
Non-timber forest products were potential assets to generate foreign exchange. Some types of which had good prospects and were in demand in the world of trade were rattan, gondorukem, eucalyptus and cassava. The purpose of this study was to determine the rattan types diversity in Rompo Village, Lore Lindu National Park. The study was conducted in December 2018 to March 2019. This research used the "survey" method by making a plot measuring $20 \mathrm{~m}$ x $20 \mathrm{~m}$ along to $1000 \mathrm{~m}$. The distance between one track to another was to $200 \mathrm{~m}$. The results showed that the type of Lambang Rattan (Calamus ornatus var celebicus Becc) had the highest density of 563.75 individuals/ha, then Pai Rattan (Calamus koordersianus Becc) 229 individuals/ha, Batang Rattan (Calamus zollingeri Becc) 183 individuals/ha, Ibo Rattan (Calamus ahlidurii) 52 individuals/ha, Rattan Tohiti Botol (Calamus sp) 46.25 individuals/ha, Pute Rattan (Calamus leiocaulis Becc ex. Heyne) 11.75 individuals/ha, Karuku Rattan (Calamus macrosphaerica Becc) 10 individuals/ha and the smallest was the type of Tohiti Wulo Rattan (Calamus sp) 9.75 individuals/ha. Rattan which had the highest Importance Value Index was the Lambang Rattan (Calamus ornatus var celebicus Becc) with an Importance Value Index value of 72.14\% while the rattan that had the lowest Importance Value Index was Tohiti Wulo Rattan (Calamus sp) with an INP value of 5.02\%. The level of species diversity (H ') of the rattan types found in the research location was classified as moderate with an $\mathrm{H}$ value of 1.75. The higher the area where the rattan is grown, the fewer types of rattan that can grow and only small rattan can grow on high ground, especially Tohiti rattan and large rattan cannot be found any more like Lambang rattan.
\end{abstract}

\section{INTRODUCTION}

In Indonesia, rattan grows almost on every island, namely Sumatra, Java, Kalimantan, Sulawesi, Maluku, Irian and Nusa Tenggara. The center of rattan distribution as well as a source of rattan production was in Kalimantan, Sulawesi and Sumatra. Specifically for Sulawesi, it could be found in the areas of Kendari, Kolaka, Buton, Towuti, Palopo, Donggala, Poso, Toli-toli, Buol, and the Latimojong mountains [1]. A total of 516 species of rattan had been recorded and known throughout Southeast Asia and as many as approximately 306 species had been identified and spread on all islands in Indonesia. Of the total identified, around 50 species had been collected, used, processed, and traded for a long time by Indonesian residents living around forests to meet local and international demand for rattan [2].

The rattan flora of Central Sulawesi is abundant, speciesrich and patchily distributed in lowland and montane forests [3]. In Sulawesi there were 7 types of rattan that had commercial value, namely batang rattan (Calamus zollingerii), tohiti rattan (Calamus inops), torumpu rattan (Calamus $s p$ ), lambang rattan (Calamus sp), jarmasin rattan (Calamus lejocoulis)), umbul rattan (Calamus simphysipus), and batu rattan (Calamus melanochaetes) [4]. In an effort to maintain or improve the condition of existing natural vegetation, especially in rattan plants that grow in forest areas in the Lore Lindu National Park, it was necessary to conduct the study to find out the types of existing rattan and its species diversity around the Lore Lindu National Park.

Rattan plants have very diverse types [5]. In addition, rattan plants also had types, characteristics and conditions of the growing environment that were quite different from one type to another [6]. Many species do not distinguish greatly between many soils with intermediate $\mathrm{pH}$ values [7]. The rattan flora of Central Sulawesi is abundant, species-rich and patchily distributed in lowland and montane forests [8]. As it was known that rattan plants could grow in almost all forest areas in Central Sulawesi. Based that case, the problem to be raised in this study was how the diversity of rattan species in the Rompo village around the Lore Lindu National Park area.

The purpose of this study was to determine the rattan types diversity in Rompo Village, Lore Lindu National Park.

\section{METHOD}

This research was conducted for 3 (three) months, from December 2018 to March 2019 in the village of Rompo in the around of the Lore Lindu National Park (TNLL) area in Central Sulawesi Province. Materials needed in this study included: 1). Tally Sheet, used to record observations. 2). Newspaper, for wrapping specimens. 3). Hanging label, to record the local name and scientific name of the type of rattan taken. 4). Spritus, to preserve the collected specimens. The 
tools used include: 1). Camera, used for documentation purposed. 2). Electrive stove, to dry the specimen. 3). Altimeter, to measure the place height. 4). Garmin GPS, for positioning or location in the field.

Based on the collected rattan data, data processing was performed to calculate the Important Value Index [9]: Important Value Index $=$ Relative Density + Relative Frequency.

- $\quad$ Density $(\mathrm{bt} / \mathrm{ha})=$ Individual amount of types / wide area

- $\quad$ Relative Density $=($ Type Density / all types density $)$ x $100 \%$

- $\quad$ Frequency $=$ Plot amount of type found $/$ all plot amount

- Relative Frequency $=$ (Type frequency $/$ all plot frequency) x $100 \%$

Spatial diversity was calculated by the Shannon-Whiener $\left(\mathrm{H}^{\prime}\right)$ Diversity index formula [10].

$$
\mathrm{H}^{\prime}=-\sum(P i l n p i)
$$

whereas, $\mathrm{pi}=\frac{n i}{N}$.
Note:

$\mathrm{H}^{\prime}=$ species diversity index;

$\mathrm{Pi}=$ Proportion of 1 st value;

$\ln =$ Natural logarithm;

$\mathrm{ni}=$ Important Value Index number of each type;

$\mathrm{N}=$ Important Value Index number of all types.

\section{RESULTS \& DISCUSSION}

\subsection{Rattan types found in the research area}

The results of observation and data collection obtained as many as 8 types of rattan as presented in Table 1 . Based on Table 1, it was known that the number of rattans in the study site was 4422 families consisting of Karuku Rattan (Calamus macrosphaerica Becc) as many as 40 families, Pute rattan (Calamus leiocaulis Becc. Ex Heyne) as many as 47 families, Pai rattan (Calamus koordersianus Becc) 916 families, Tohiti Botol rattan (Calamus Sp) 185 families, Lambang symbol (Calamus ornatus var celebicus Becc) 2255 families, Tohiti Wulo rattan (Calamus $S p$ ) 39 families, Batang rattan (Calamus zollingeri Becc) 732 families and Ibo rattan (Calamus ahlidurii) family 39 .

Table 1. Types and amounts of rattan in the study area

\begin{tabular}{cccc}
\hline No & Local Name & Species & Amount \\
\hline 1. & Rattan Lambang & Calamus ornatus var celebicus Becc & 2255 \\
2. & Rattan Pai & Calamus koordersianus Becc & 916 \\
3. & Rattan Batang & Calamus zollingeri Becc & 732 \\
4. & Rattan Ibo & Calamus ahlidurii & 208 \\
5. & Rattan Tihiti Botol & Calamus $s p$ & 185 \\
6. & Rattan Pute & Calamus leiocaulis Becc.ex Heyne & 47 \\
7. & Rattan Karuku & Calamus Macrosphaerica Becc & 40 \\
8. & Rattan Tohiti Wulo & Calamus $s p$ & 39 \\
\hline \multicolumn{3}{c}{ Total } \\
\hline
\end{tabular}

Generally, the shape and nature of rattan can be distinguished based on the number of stems per clump, rooting system, the form of climbing tools, the form of leaf, flower and fruit development [11]. The number of stems per clump varies depending on the type, there is a single stem ("solitary") and there is a group / cluster ("cluster"). The creation of comprehensive indigenous classification systems for rattans also demonstrates the social significance of rattans, which have become a representation of rattans as they grow in the forest as well as how they are used [12]. For example, many names can refer to a widespread species because its range includes a number of language groups. Sometimes, several names can be given to one species that represent the different uses or the different phases of development of the plant from young to adult. Blanket names for "cane" are typically given to a large variety of species [12].

\subsection{Rattan types characteristics}

\subsubsection{Rattan Karuku (Calamus macrosphaerica Becc)}

The Karuku type of rattan was slim and lives solitary or in clumps. It had a very hard stem with a stem length of up to 25 $\mathrm{m}$ and a stem diameter with a leaf heat of $2 \mathrm{~cm}$. The stem was overgrown with thorns that were very dense and swollen, $1 \mathrm{~cm}$ long, triangular in shape as wide as $0.3 \mathrm{~cm}$. The diameter of the stem without the midrib $1.5 \mathrm{~cm}$, length $16-20 \mathrm{~cm}$ and white. Pangan leaves with a length of up to $2 \mathrm{~m}$ with one pair of spines every $1 \mathrm{~cm}$ and black spines. The Karuku rattan Figures and their specimens were presented in Figure 1.
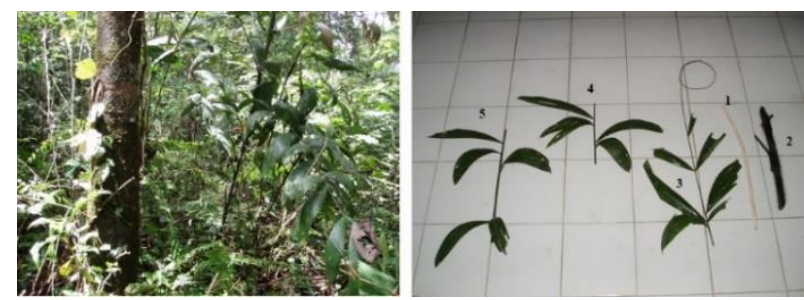

Figure 1. Rattan Karuku type, habitat, and specimen Note: 1). Rattan sticks without sheath. 2). Leaf sheath. 3). The tips of the leaves with pigtails (Cirrus). 4). The middle part of the leaf. 5). The base of the leaf

\subsubsection{Rattan Pute (Calamus leiocaulis Becc. ex Heyne)}

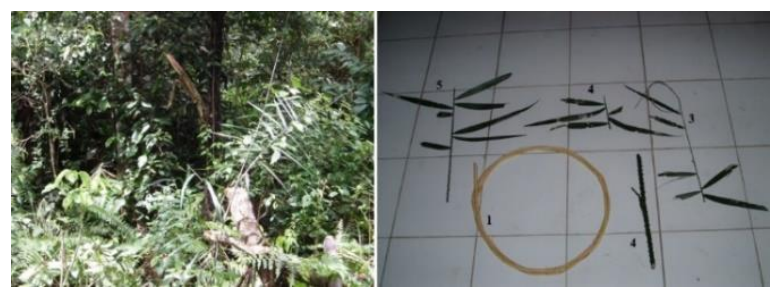

Figure 2. Pute Rattan type, habitat, and specimen Note: 1). Rattan stem without stem, 2). Leaf sheath, 3). The tips of the leaves with pigtails (Cirrus), 4). The middle part of the leaf, 5). The base of the leaf 
Slim and solitary rattan, the stem could reach $42 \mathrm{~m}$ in height, the length of the leaf with $1 \mathrm{~m}$ petioles midrib, had a cirrus with a length of $50 \mathrm{~cm}$. The thorns attached to the stem were very short and rarely $0.5 \mathrm{~cm}$ long, the stem diameter without leaves to $7 \mathrm{~mm}$. The Figure s of Pute rattan and its specimens were presented in Figure 2.

\subsection{Rattan pai (Calamus koordersianus Becc)}

Rattan clumped but sometimes solitary. Stem diameter without leaf fronds $17-20 \mathrm{~mm}$, with leaf fronds $30-40 \mathrm{~m}$. Twisted leaves with a length of $2.8 \mathrm{~m}$ overgrown with thorns like a curved anchor, flagella length reaches $2.5 \mathrm{~m}$. Leaves up to $2 \mathrm{~m}$ long, old green leaf fronds overgrown with long thorns in the shape of triangles up to $3 \mathrm{~cm}$, knee striking, covered with short spines totaling 5 in the middle, short octree, $0.4 \mathrm{~m}$ long petiole, overgrown with short spines on the part top, leaflets up to 40 pairs, arranged orderly, missed, prickly at the edges of the leaves. The Figures of Pai rattan and their specimens were presented in Figure 3.
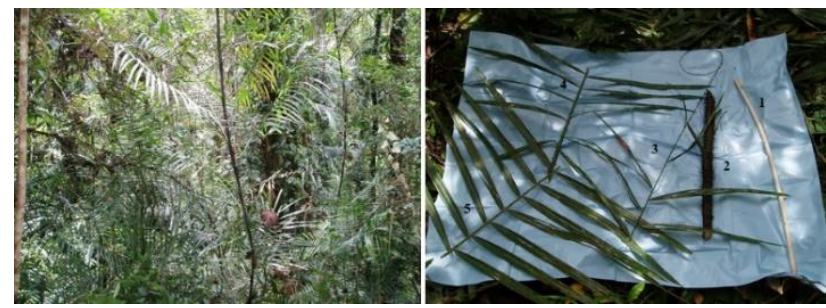

Figure 3. Pai Rattan type, habitat, and specimen Note: 1). Rattan stem without stem, 2). Leaf sheath; 3). The tips of the leaves with pigtails (Cirrus), 4). The middle part of the leaf, 5). The base of the leaf

\subsection{Rattan Tohiti Botol (Calamus sp)}

Rattan was rather sturdy and clumped, leaves with rachis 60 $\mathrm{cm}$ long, consisting of 8 leaflets which were facing each other (folio opposite) and had a ponytail whose length reaches 1.5 $\mathrm{m}$, the stem of an old green colored leaf, surrounded by thorns. The Figure of the Tohiti Botol rattan and its specimens were presented in Figure 4.

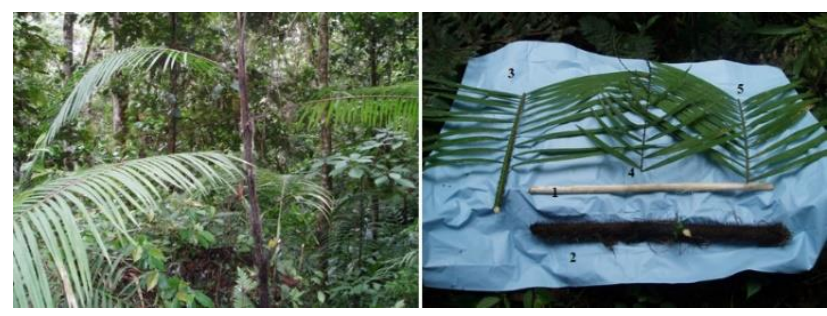

Figure 4. Tohiti Botol Rattan type, habitat, and specimen Note: 1). Rattan stem without stem, 2). Leaf sheath, 3). The base of the leaf, 4). The tips of the leaves with pigtails (Cirrus), 5). The middle part of the leaf

\subsection{Lambang rattan (Calamus ornatus var. celebicus Becc)}

The bush collapsed massively, climbing $50 \mathrm{~cm}$ high. The diameter of the stem with a leaf flap reached $70 \mathrm{~mm}$, the diameter of the leaf without the leaf flaps up to $40 \mathrm{~mm}$, the stem book (node) stood out, the distance between the books to $30 \mathrm{~cm}$. Leaves massive, leaflets pale green to dark green, growing black thorns with varying thicknesses, triangular in shape, slender to large, yellowish at $4 \mathrm{~cm} \mathrm{x} 1 \mathrm{~cm}$, the thorns were set irregularly and slightly pointed, knees pointed, short okrea, ragged.

It had a greenish-green flagellum, up to $10 \mathrm{~m}$ long, with black spines with a yellow base in a partial circle, a stalk of leaves, up to $1 \mathrm{mx} 4 \mathrm{~cm}$, usually less, at most leaves, 20 - 30 on each side, the bottom $50 \mathrm{~cm} \times 5 \mathrm{~cm}$, the largest located in the middle, $80 \mathrm{~cm} \times 8 \mathrm{~cm}$, progressing to the smallest tip, $4 \mathrm{~cm}$ $\mathrm{x} 0.5 \mathrm{~cm}$, with a lattice forming horizontally, the upper surface of the blade clearly near the tip and along the main vein. The rattan image of the Symbol and its specimen were presented in Figures 5.

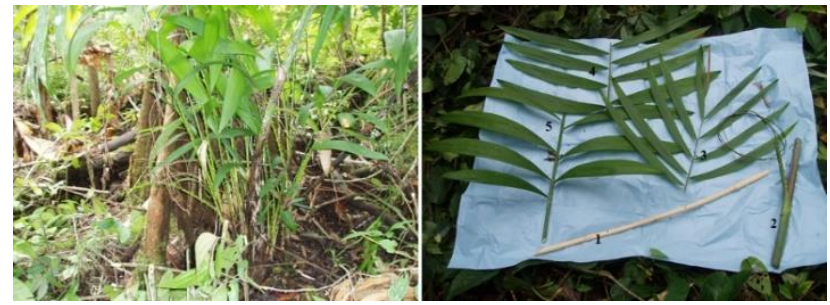

Figure 5. Rattan type Lambang, habitat, and specimen Note: 1). Rattan rod without flakes, 2). Blisters and flagella, 3). The tip of the leaf, 4). The middle of the leaf, 5). The base of the leaf

\subsection{Rattan Tohiti Wulo (Calamus sp)}

Rigid and solitary rods, trunk length up to $30 \mathrm{~m}$. Petiolus leaf length up to $2.5 \mathrm{~m}$. Leaf leaves with a length of $1.5 \mathrm{~m}$, spines on cirrus number 9 each $4 \mathrm{~cm}$ long. Stem with $30 \mathrm{~mm}$ diameter slit, $20 \mathrm{~mm}$ non-fringed stem. Knee (knee) prominent, spines sparse at $17 \mathrm{~mm}$ long. Leaves pale in color from young to dark green, with spines sparse and irregularly spaced $17 \mathrm{~mm}$ long, yellowish-triangular, short oval. The wick drawings of Tohiti Wulo and his specimens were shown in Figures 6.
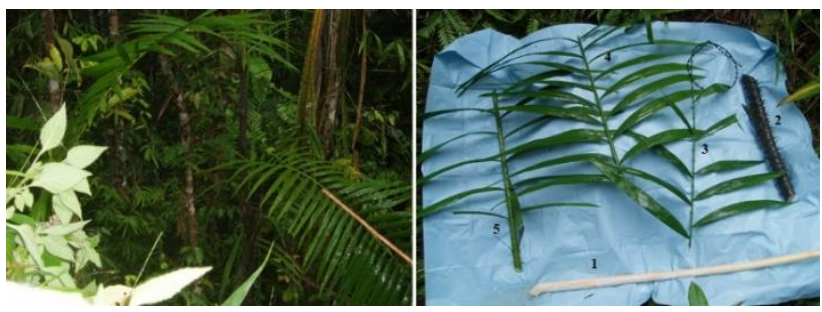

Figure 6. Tohiti Wulo Rattan type, habitat, Specimen Note: 1 . Rattan rod without flakes; 2 . Leaf; 3 . The tip of the leaf with the coriander (cirrus); 4 . The middle of the leaf; 5 . The base of the leaf

\subsection{Rattan batang (Calamus zollingeri Becc)}

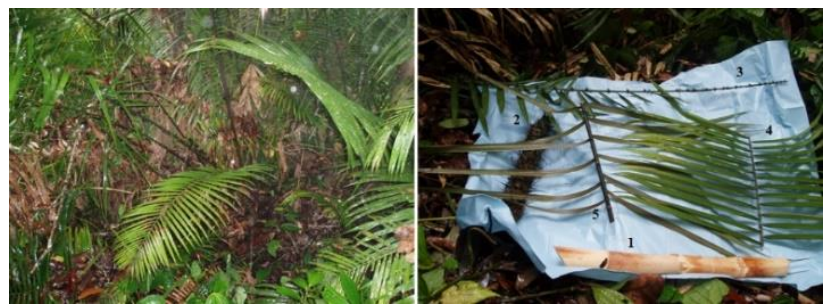

Figure 7. Batang Rattan type, habitat, Specimen Note: 1. Rattan rod without flakes; 2 . Leaf; 3 . Leaf tip with calyx (Cirrus); 4. The middle of the leaf; 5 . The base of the leaf

Rigid and clustered, it could reach 90 stems in one clump. Stems were dark green, reddish-brown. Its length was $40 \mathrm{~m}$, its leaf diameter was $25-40 \mathrm{~mm}$, its leaf diameter was $60 \mathrm{~mm}$, 
its length was $40 \mathrm{~cm}$. Leaf-shaped leaves, up to $7 \mathrm{~m}$ long including $80 \mathrm{~cm}$ long, $5 \mathrm{~m}$ long rachis with $2 \mathrm{~m}$ lateral, which were covered with anterior anchor-like thorns, 30 - $40 \mathrm{~cm}$ long leaflets, dull green, densely spines. wide triangular, dark brown to black, $5.5 \mathrm{~m}$ long, 8 - 12 thorns side by side often united in 2.5-cm long collar, knee-high; there were no thorns on the upper surface, thorns up to $3 \mathrm{~cm}$ long, resembling thorns on the leaf blade, leaflets $60-85$ on each side of the rachis, arranged in order, bending, oblong, up to $50 \mathrm{~cm} \mathrm{x} 3 \mathrm{~cm}$, with sideways vein, upper and lower leaf blossom leaves $2.5 \mathrm{~cm}$ long, $1.4 \mathrm{~cm}$ apart, leaves $25-30 \mathrm{~mm}$ wide. As for the rattan rods and their specimens were presented in Figures 7.

\subsection{Rattan Ibo (Calamus ahlidurii)}

The shrubs were sometimes solitary, reaching a height of 15 $\mathrm{m}$. The leaves were $1.5 \mathrm{~m}$ long, with dorsal and spines on the rachis. The dorsal length reaches $1 \mathrm{~m}$, the ends of the stems were reddish-coated by thick thorns. Thorn $3-4 \mathrm{~cm}$ long black. Stem without a blade diameter $1.5 \mathrm{~cm}$, stalk $5 \mathrm{~cm}$, trunk length (internodus) $12 \mathrm{~cm}$ and knee (knee) were found on the blade, surrounded by thick, black thorns. As for the Ibo rattan images and their specimens were presented in Figure 8.

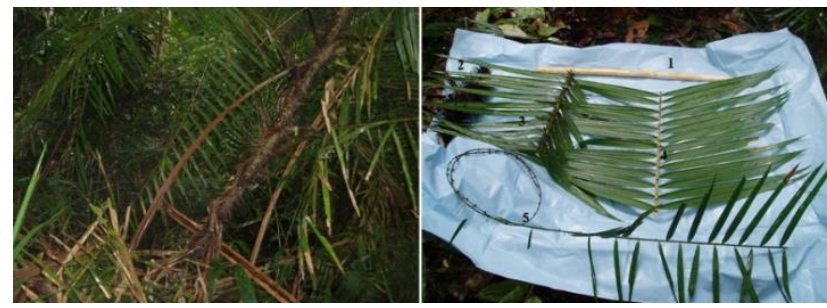

Figure 8. Ibo Rattan type, habitat, Specimen

Note: 1. Rattan rod without flakes; 2. Leaf; 3 . The base of the leaf; 4 . The middle of the leaf; 5. Leaf tip with calyx (Cirrus)

\subsection{Rattan composition types}

Based on the results of observation and identification of rattan types in the research area, 8 (eight) rattan varieties were found (Table 2). The composition of the rattan type based on the results of the Important Value Index (INP) calculation was presented in Table 2.

Based on the data in Table 2 it was shown that of the eight types of rattan found at the study site, the Lambang rattan (Calamus ornatus var celebicus Becc) had the highest density of 563.75 individuals/ha, and then the Pai Rattan (Calamus koordersianus Becc) 229 individuals/ha, Batang rattan (Calamus zollingeri Becc) 183 individuals/ha, Ibo rattan (Calamus ahlidurii) 52 individuals/ha, Tohiti Botol rattan (Calamus sp) 46.25 individuals/ha, Pute rattan (Calamus leiocaulis Becc. Ex.Heyne) 11, 75 individuals/ha, Karuku rattan (Calamus macrosphaerica Becc) 10 individuals/ha, and the smallest species was Wulo Tohiti (Calamus sp) 9.75 individuals/ha.

The most common type of rattan dispersion found in each observation plot was the Lambang Rattan (Calamus ornatus var celebicus Becc) with $21.15 \%$ dispersion rate, while the lowest type of rattan was Tohiti Wulo (Calamus sp) was $4.14 \%$. The types of rattan that dominate the research area based on the highest INP were Lambang Rattan (Calamus ornatus var celebicus Becc) with INP of $72.14 \%$ then Pai Rattan (Calamus koordersianus Becc) with INP 39.34\%, Batang rattan (Calamus zollingeri Becc) with INP $33.79 \%$, Rattan Ibo (Calamus ahlidurii) with INP of $18.50 \%$, Tohiti Botol rattan (Calamus sp) with INP of $17.29 \%$, Pute Rattan (Calamus leiocaulis Becc ex. Heyne) with INP of 7.96\%, Karuku Rattan (Calamus macrosphaerica Becc) with INP of $5.96 \%$, Tahiti Wulo Rattan (Calamus sp) with INP of 5.02\%.

Table 2. Rattan types compositions at the research locations

\begin{tabular}{|c|c|c|c|c|c|}
\hline Local Name & Species & $\begin{array}{l}\text { Density } \\
\text { (Ind/ha) }\end{array}$ & $\begin{array}{c}\text { Relative Density } \\
(\%)\end{array}$ & $\begin{array}{c}\text { Relative Frequency } \\
(\%)\end{array}$ & $\begin{array}{c}\text { Important Value Index } \\
(\%)\end{array}$ \\
\hline Rotan Lambang & Calamus ornatus var Celebicus Becc & 563.75 & 51 & 21.15 & 72.14 \\
\hline Rotan Pai & Calamus koordersianus Becc & 229 & 20.71 & 18.62 & 39.34 \\
\hline Rotan Batang & Calamus zollingeri Becc & 183 & 16.55 & 17.24 & 33.79 \\
\hline Rotan Ibo & Calamus ahlidurii & 52 & 4.7 & 13.79 & 18.5 \\
\hline Rotan Tohiti Botol & Calamus sp & 46.25 & 4.18 & 13.1 & 17.29 \\
\hline Rotan Pute & Calamus leiocaulis Becc. ex. Heyne & 11.75 & 1.06 & 6.9 & 7.96 \\
\hline Rotan Karuku & Calamus macrosphaerica Becc & 10 & 0.9 & 5.06 & 5.96 \\
\hline Rotan Tohiti Wulo & Calamus sp & 9.75 & 0.88 & 4.14 & 5.02 \\
\hline Total & 1105.5 & & 100 & 00 & 200 \\
\hline
\end{tabular}

Table 3. Biodiversity index at research locations

\begin{tabular}{cccc}
\hline Local Name & Species & Important Value Index (\%) & H' \\
\hline Rattan Lambang & Calamus Ornatus var celebicus Becc & 72.14 & 0.37 \\
Rattan Pai & Calamus koordesianu Becc & 39.34 & 0.32 \\
Rattan Batang & Calamus zollingeri Becc & 33.79 & 0.30 \\
Rattan Ibo & Calamus ahlidurii & 18.50 & 0.22 \\
Rattan Tohiti Botol & Calamus sp & 17.29 & 0.21 \\
Rattan Pute & Calamus leiocaulis Becc ex. Hayne & 7.96 & 0.13 \\
Rattan Karuku & Calamus macrosphaerica Becc & 5.96 & 0.10 \\
Rattan Tohiti Wulo & Calamus sp & 5.02 & 0.09 \\
\hline \multicolumn{2}{c}{ Amount } & 200 & 1.75 \\
\hline
\end{tabular}

\subsection{Types diversity indexes}

The type of diversity index reflects the degree of diversity in a community, the high diversity of a community indicates the stability or stability of the ecosystem. The higher the value of the diversity of the species, the greater the degree of 
diversity.

Classified the level of diversity of a species based on the diversity index into 3 criteria: H' $0-2=$ indicates low species diversity level, H' $2-3$ = indicates moderate species diversity level, $\mathrm{H}^{\prime}>3=$ indicates high species diversity level [13]. From the results of the ratios diversity index calculation at the study site, it was obtained from the rattan type diversity index as presented in Table 3.

Based on Table 3 it was shown that the diversity of type $(\mathrm{H}$ ') rattan found at the study site classified as the low, with a value of $\mathrm{H}^{\prime}$ of 1.75. The greater the number of species found, the higher the diversity index obtained [14].

Various types of rattan are available to make it easier to choose the availability of rattan raw materials that are increasingly scarce, so it needs mapping the types of rattan and indeed certain types of rattan are only located at a certain height, especially the rare Tohiti rattan and only at a height of 1000 meters above sea level. The advantages of certain types of rattan are Tohiti besides being rare, export quality and the price is expensive [15].

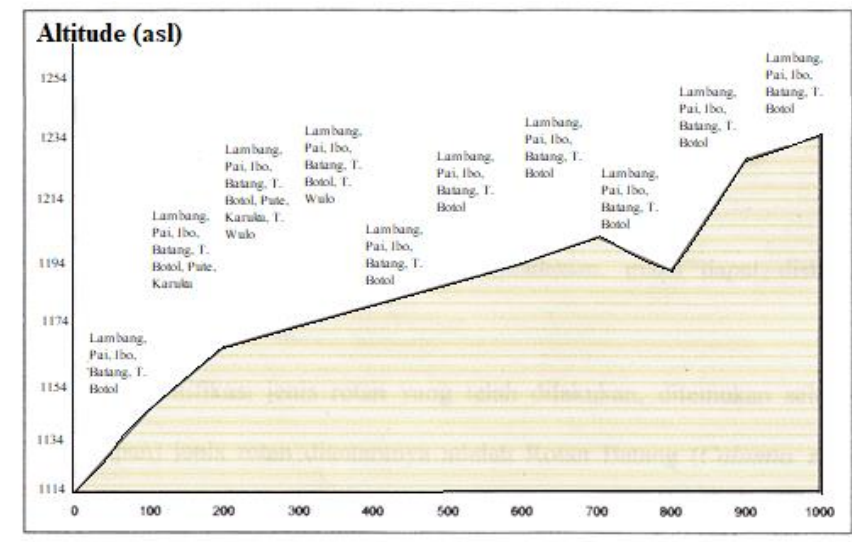

Distance (Meters)

Figure 9. Observation plot transects at research locations

Based on the Figure 9 types of symbol rattan (calamus ornatus var celebicus Beec), Pal (Calamus koordersianus Becc), Ibo (Calamus ahlidurii), Trunk (Calamus zollingeri Becc), Tohiti Botol (Calamus sp) are found at every height while Pute rattan (Calamus ahlidurii), Trunk (Calamus zollingeri Becc), Tohiti Botol (Calamus sp) are found at each height while Pute rattan (Calamus leiocaulis) Bece ex. Heyne), Karuku (Calamus macrosphaerica Becc), Tohiti Wulo (Calamus sp) only found at an altitude of 1,135 - $1178 \mathrm{~m}$ asl.

Figure 9 provides more detailed information on the existence of rattan species, namely the higher the area where the rattan is grown, the fewer types of rattan that can grow and only small rattan can grow on high ground, especially Tohiti rattan and large rattan cannot be found any more like Lambang rattan

Types of rattan that are easily obtained and widely used by the community for local consumption are rattan rods and symbols because it grows below 500 asl and the price is not too expensive, can be used for making household materials such as chairs / sofas, shelves, tables and cabinets [16]. It is expected that from the mapping of rattan obtained can be made permanent plots for nurseries at each growth height so that certain types of rattan are not extinct [11] and can increase Regional Original Revenue [17]. The main objective of rattan inventory is to use the data for planning protective strategy in managing depleting resources [18].

\section{CONCLUSIONS}

The rattan that has the highest Importance Value Index is the Rattan Lambang (Calamus ornatus var celebicus Becc) with an Importance Value Index value of $72.14 \%$ while the Rattan that has the lowest Importance Value Index is the Rattan Tohiti Wulo (Calamus sp) with an Importance Value Index value at $5.02 \%$. The level of species diversity $\left(\mathrm{H}^{\prime}\right)$ of the Rattan type found in the study location is classified as low with an $\mathrm{H}$ value of 1.75 .

Lambang Rattan type (Calamus ornatus var celebicus Becc) had the highest density of 563.75 individuals/ha, then Pai Rattan (Calamus koordersianus Becc) 229 individuals/ha, Batang Rattan (Calamus zollingeri Becc) 183 individuals/ha, Ibo Rattan (Calamus ahlidurii) 52 individuals/ha, Tohiti Botol Rattan (Calamus sp) 46.25 individuals/ha, Pute Rattan (Calamus leiocaulis Becc ex. Heyne) 11.75 individuals/ha, Karuku Rattan (Calamus macrosphaerica Becc) 10 individuals/ha and the smallest were Tohiti Wulo Rattan type (Calamus sp) 9.75 individuals/ha.

Further research is needed in various Lore Lindu National Park Areas in order to obtain more types of rattan and there is also a need for nurseries of various types of rattan to further increase the diversity of their species while preserving the rattan plant.

\section{ACKNOWLEDGMENT}

Tadulako University for all the facilities provided so that this research can be carried out well.

\section{REFERENCES}

[1] Meijaard, E., Achdiawan, R., Wan, M., Taber, A. (2014). Rattan: The decline of a once-important non-timber forest product in Indonesia. Occasional Paper 101. Bogor, Indonesia: CIFOR.

[2] Januinro. (2000). Indonesia: potensi, budi daya, pemungutan, pengolahan, standar mutu, dan prospek pengusahaan. Penerbit Kanisius. https://books.google.co.id/books/about/Rotan_Indonesia .html?id=N12zAAAACAAJ\&redir_esc $=y$.

[3] Kalima, T., Prameswari, D. (2018). Natural regeneration population of batang rattan (Calamus zollingeri Beccari) in nupabomba village, production forest area, central sulawesi. Jurnal Manajemen Hutan Tropika, 24(3): 175185. https://doi.org/10.7226/jtfm.24.3.175

[4] Alam, A.S, Pribadi, H., Suraidah., S. (2021). Revenue optimization analysis of rattan furniture industry in Palu City, Central Sulawesi, Indonesia (Case Study in PT Meubel Rotan Subur). Advances in Biological Sciences Research. 11: 58-64. https://dx.doi.org/10.2991/absr.k.210408.010

[5] Yang, S., Shang, L., Tian, G., Ma, J. (2020). Comparison of physical and mechanical properties of four rattan species grown in China. Journal of Wood Science, 66(1): 1-8. https://doi.org/10.1186/s10086-020-1850-0

[6] Dransfield, J. (2002). The Resource, Its Uses and Present Action http://www.fao.org/3/y2783e/y2783e06.htm. Programmes.

[7] Pritchett, R., Phillips, A., Mardiastuti, A., Powling, A. (2016). Rattan diversity and broad edaphic niches in a 
tropical rainforest of Buton, Sulawesi, Indonesia. REINWARDTIA, 15(2): 99-110. https://doi.org/10.14203/reinwardtia.v15i2.2943

[8] Kalima, T., Prameswari, D. (2018). Natural Regeneration Population of Batang Rattan (Calamus zollingeri Beccari) in Nupabomba Village, Production Forest Area, Central Sulawesi. Jurnal Manajemen Hutan Tropika, 24(3): 175185. https://doi.org/10.7226/jtfm.24.3.175

[9] Ismail, M.H., Fuad, M.F.A., Zaki, P.H., Jemali, N.J.N. (2017). Analysis of importance value index of unlogged and logged peat swamp forest in Nenasi Forest Reserve, Peninsular Malaysia. Bonorowo Wetland, 7(2): 74-78. https://doi.org/10.13057/bonorowo/w070203

[10] Ludwig, J.A., Quartet, L., Reynolds, J.F., Reynolds, J.F. (1988). Statistical Ecology: A Primer in Methods and Computing. New York. John Wiley and Sons.

[11] Tellu, A.T. (2008). Chemical properties of different rattan species traded in Central Sulawesi Province. Biodiversitas, 9(2): 108-111.

[12] Dransfield, J. (2001). Taxonomy, biology and ecology of rattan. UNASYLVA-FAO, 52: 11-13.

[13] Rotinsulu, J.M., Suprayogo, D., Guritno, B., Hairiah, K. (2013). The Potential of Rubber Agroforestry for Rattan (Calamus Sp) Cultivation in Katingan Regency: Diversity of Climbing Trees for Rattan. Agrivita, 35(3):
277-289. https://doi.org/10.17503/Agrivita-2013-35-3p277-289

[14] Siebert, S.F. (2005). The abundance and distribution of rattan over an elevation gradient in Sulawesi, Indonesia. Forest Ecology and Management, 210(1-3): 143-158. https://doi.org/10.1016/j.foreco.2005.02.015

[15] Komaruddin, H., Siagian, Y., Oka, N.P. (2006). The advantages of certain types of rattan are Tohiti besides being rare, export quality and the price is expensive. Research Workshop on Collective Action and Market Access for $\quad$ Smallholders. 27 . http://www.itto.int/files/itto_project_db_input/2400/Tec hnical/TR_plantation_final.pdf.

[16] Ngo-Samnick, E.L. (2012). Production and Processing of Rattan. CTA.

[17] Resosudarmo, B., Yusuf, A.A., Hartono, D., Nurdianto, D. (2011). Regional economic modelling for Indonesia: implementation of IRSA-Indonesia 5. Journal of Indonesian Economy and Business, 26(3): 287-309.

[18] Hamid, N.H.A., Suratman, M.N. (2010). Assessment of rattan abundance and species composition at Kuala Keniam, Taman Negara Pahang. In 2010 International Conference on Science and Social Research (CSSR 2010) pp. 1041-1046. 